ARTICLE

\title{
Reproductive aspects of Chiton virgulatus in Bahía de La Paz, Gulf of California, Mexico
}

\author{
Aspectos reproductivos de Chiton virgulatus en Bahía de La Paz, Golfo de California, \\ México
}

\section{Nurenskaya Vélez-Arellano ${ }^{1}$, Federico Andrés García-Domínguez ${ }^{1,2^{*}}$, Oscar Efraín Holguin-Quiñones ${ }^{1}$ and Maclovio Obeso-Nieblas ${ }^{1,2}$}

\author{
'Instituto Politécnico Nacional, Centro Interdisciplinario de Ciencias Marinas, Av. Instituto Politécnico Nacional s/n Col. Playa Palo de \\ Santa Rita, Apartado Postal 592, La Paz, Baja California Sur, México \\ ${ }^{2}$ Becario de la Comisión y Fomento de Actividades Académicas del IPN y estímulo al desempeño de los investigadores del IPN \\ *Corresponding author: fdoming@ipn.mx
}

\begin{abstract}
Resumen.- Se analizó el ciclo reproductivo de Chiton virgulatus y su relación con la temperatura superficial del mar y aire (TSM, TA), el fotoperiodo y el ciclo de mareas (CM) en Bahía de La Paz en la costa del Golfo de California. Se tomaron muestras mensuales de septiembre de 2008 a septiembre de 2009. Se registró la longitud, el peso total y peso de la gónada de cada organismo, la gónada fue procesada usando una técnica histológica, se estimó el índice gonádico y la longitud de primera madurez (L50). C. virgulatus presenta desoves parciales con un pico reproductivo en verano y otoño (julio-diciembre). La frecuencia de organismos maduros estuvo asociada con los aumentos de $\operatorname{TSM}\left(30,6^{\circ} \mathrm{C}\right)$, $\operatorname{TA}\left(29,9^{\circ} \mathrm{C}\right)$ y CM $(68 \mathrm{~cm}$, pleamar), mientras que el fotoperiodo (días más largos) moduló la frecuencia de organismos en desarrollo. La longitud de primera madurez fue de 29,7 mm. Chiton virgulatus es un poliplacóforo al que las altas temperaturas y el nivel de marea alto, influyen en el momento reproductivo, mientras que un aumento en la luz del día favorece el desarrollo gonádico.
\end{abstract}

Palabras clave: Gónada, factores ambientales, Poliplacóforos, talla de primera madurez

\begin{abstract}
This study analyzed the reproductive cycle of Chiton virgulatus and its relationship with air temperature (AT) sea and surface temperature (SST), photoperiod, and tidal cycle (TC) in Bahía de La Paz, in the coast of the Gulf of California. Monthly samples were collected from September 2008 to September 2009. The parameters recorded included total length, total weight, and gonad weight of each organism; the gonad was processed using a histological technique, and the gonadal index and length at first maturity (L50) were estimated. C. virgulatus displays partial spawning with a reproductive peak in summer and autumn (July to December). The frequency of ripe organisms was associated with rises in SST $\left(30.6^{\circ} \mathrm{C}\right)$, AT $\left(29.9^{\circ} \mathrm{C}\right)$, and TC $(68 \mathrm{~cm}$, high tidal), while photoperiod (longer days) regulated the frequency of developing organisms. The length at first maturity was $29.7 \mathrm{~mm}$. Chiton virgulatus is a polyplacophoran species in which high temperatures and high tides influence reproductive timing, while an increase in daylight boosts gonad development.
\end{abstract}

Key words: Gonad, environmental factors, Polyplacophora, length at first maturity

\section{INTRODUCTION}

Two polyplacophoran species, Chiton articulatus (Sowerby in Broderip and Sowerby, 1832) and Stenoplax magdalenensis (Hinds, 1845), are exploited intensively and with no restriction throughout their distribution range along the Mexican Pacific coast for use as human food, as bait for lobster fishing, and for manufacturing handicrafts (Ríos-Jara et al. 2006). Chiton virgulatus Sowerby II, 1840 is a species endemic to the coasts of the Gulf of California (Gonzalez 1993), for which no studies addressing its abundance are available. However, this species may be a resource with fishery potential.
The existing studies on $C$. virgulatus describe the oogenesis of this species considering three oocyte development stages (previtellogenic oocyte, immature vitellogenic oocyte, and mature vitellogenic oocyte) (Vélez-Arellano et al. 2014). Besides, some studies also describe the diversity of diatoms in the diet of $C$. virgulatus and conclude that diatoms are not the only food source for this species (Siqueiros-Beltrones \& Argumedo-Hernandez 2012). Studies on the reproductive cycle of $C$. articulatus in Mexico are scarce (Rojas-Herrera 1988, HolguinQuiñones \& Michel-Morfín 2002, Flores-Campaña et al. 2007, García-Ibáñez et al. 2013, Morfin-Jiménez et al. 2014, Ramírez-Álvarez et al. 2014). 
The proper management of a fishery resource, whether overexploited, under exploitation, or with exploitation potential, demands a thorough knowledge of its reproductive cycle, as this allows identifying the spawning season, estimating the size at reproductive recruitment, and setting a minimum catch size (Baqueiro et al. 1992). In studying the reproduction of many marine invertebrates, the histological examination of gonadal tissue is the most reliable method to recognize seasonal gonadal changes and determine the frequency and duration of spawning in a natural population (Jaramillo \& Navarro 1995, Barón \& Ciocco 2001). Other approaches for examining the reproductive cycle rely on calculating gonad, digestive gland and muscle performance indices (Villalejo-Fuerte \& Ceballos-Vázquez 1996) and analyzing the monthly average diameter of oocytes (Grant \& Tyler 1983).

A number of studies have described the reproductive cycle of various polyplacophoran species, including Katharina tunicata (Wood, 1815) (Giese et al. 1959, Himmelman 1978), Mopalia hindsii (Sowerby MS, Reeve, 1847) (Giese et al. 1959), Acanthopleura japonica (Lyschke, 1873) (Yoshioka 1987a, b), Chiton cumingsii Frembly, 1827 (Ishiyama 1995), Acanthopleura gemmata (Blainville, 1825) (Soliman et al. 1996, Barbosa et al. 2009), and several Lepidochitona species: L. dentiens (Gould, 1846), L. hartwegii (Carpenter, 1855), L. berryana Eernisse, 1986, L. thomasi (Pilsbry, 1898), L. caverna Eernisse, 1986, and L. fernaldi Eernisse, 1986 (Eernisse 1988).

The reproductive cycles of marine invertebrates are usually determined by interactions between exogenous (e.g., photoperiod, tidal level, and temperature) (Rose et al. 1990), as well as by endogenous factors (e.g., endocrine and neuronal) (López et al. 2005). Thus, reproductive periodicity in these organisms is regulated not only by the genome but also by variations in abiotic factors (Mackie 1984) acting as environmental signals that trigger gonadal maturation. This is particularly the case in intertidal zones inhabited by chitons, which are ecosystems permanently subjected to environmental fluctuations (Sakker 1986, Yoshioka 1987a). Reproductive cycles can be annual, biannual, seasonal, or continuous, depending on the particular locality and species (Sastry 1979).

The reproductive cycles of polyplacophoran species inhabiting Mexican coasts have been little investigated to date; the only species studied so far is Chiton articulatus (Avila-Poveda 2013, Morfin-Jiménez et al. 2014, RamírezÁlvarez et al. 2014, Abadía-Chanona 2015). In this study, the reproductive cycle and the size at the first maturity of $C$. virgulatus were determined along with establishing its relationship with air and sea surface temperature, photoperiod, and tides in Bahía de La Paz, Gulf of California, México.

\section{Materials AND MethodS}

The sampling area was Bahía de La Paz, Baja California Sur, Mexico, located at $24.1-24.8^{\circ} \mathrm{N}$ and $110.2-110.8^{\circ} \mathrm{W}$. This is the largest bay on the eastern coast of the Baja California peninsula. C. virgulatus specimens were harvested monthly in the intertidal zone of the rocky beach El Califin (2419'16"N, 110³8'27'W) (Fig. 1) from September 2008 to September 2009. Averages of 25 specimens were monthly and randomly collected. Body mass and total length of the specimens collected was recorded. All specimens were deshelled and dissected to remove the gonad; the gonad weight was recorded. Convectional histological analysis was done following gonad immersion in formalin (10\%) prepared in filtered seawater for $48 \mathrm{~h}$, then dehydrated and embedded in paraffin. Several $5 \mu$ m-thick sections were obtained and stained using Harris' hematoxylin-eosin and Masson's trichrome techniques (Luna 1968). Specimens were sexed by examining photomicrographs of slides captured with a Leica DMLS. Based on the study by Barbosa et al. (2009) and the morphological characteristics observed, the gonadal cycle of $C$. virgulatus was divided into four stages (undifferentiated, developing, mature and spawning).

The diameter of 100 oocytes selected at random from each gonad of developing or mature females were measured according to Grant \& Tyler (1983), using the software Sigma Scan Pro Version 5 (Systat Software, Inc., USA).

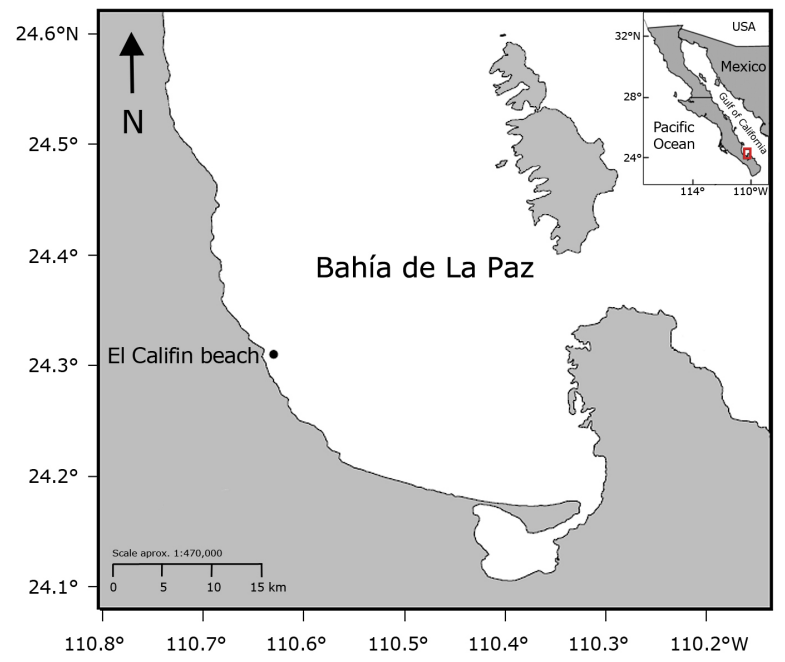

Figure 1. Study area: El Califín beach, Bahía de La Paz, Gulf of California Mexico / Área de estudio: Playa El Califín, Bahía de La Paz, Golfo de California, México 
Length at first maturity (L50) is defined as the one at which $50 \%$ of all organisms are sexually mature (Somerton 1980). In order to, the frequency of mature and spawning organisms was obtained considering $2 \mathrm{~mm}$ size intervals. The relative frequency and cumulative relative frequency were calculated to define the range of length at first maturity, using the following equation:

$$
Y=\frac{1}{1+e(a+b L t)}
$$

Where $Y$ is the proportion of mature and spawning organisms; $L t$ is total length (mm); and $a$ and $b$ are constants.

The gonad index (GI) was calculated as defined by Villalejo-Fuerte \& Ceballos-Vázquez (1996), by dividing gonad weight by total weight; the gonad index was an indicator of the complete reproductive cycle.

Sea surface temperature (SST) was recorded at the time of harvest with a mercury thermometer; air temperature (AT) data were obtained from the meteorological station at La Paz city; photoperiod and tidal cycle (TC) data were obtained from the MARv09 program provided by CICESE in Ensenada, Baja California, Mexico (CICESE) ${ }^{1}$.

The correlations between the indices, gonad stage, and environmental variables (SST, AT, CM) were examined with the Spearman's rank correlation coefficient (Spearman 1904), and statistical significance was evaluated with the Student's $t$-test for $n$ (number of data) and $n$ - 2 degrees of freedom (Zar 2010), A chi-square test showed the significant difference in the sex ratio $(P>0.05)$. Monthly variations in oocyte diameter and GI were analyzed through a nonparametric test (Kruskal-Wallis test). All the statistical tests were run using the Statistica 8.0 software (StatSoft Inc., USA).

\section{ReSUlts}

\section{ENVIRONMENTAL PARAMETERS}

Monthly SST, AT, photoperiod, and tidal cycle data are shown in Figure 2. SST maximum temperature was recorded in September $2008\left(30.6^{\circ} \mathrm{C}\right)$ and decreased steadily until February $2009\left(18.1^{\circ} \mathrm{C}\right)$. The highest AT was recorded in September $2008\left(29.9^{\circ} \mathrm{C}\right)$, decreasing gradually to $19.9^{\circ} \mathrm{C}$ in January 2009 , and then rising steadily again to reach its highest value, $31.8^{\circ} \mathrm{C}$, in August 2009. As for photoperiod, the longest days were recorded in June and July, and the shortest in December and January. The tide cycle showed its highest values in September 2008 and 2009 (68.9 and $68.5 \mathrm{~cm}$, respectively); it dropped gradually from September 2008 to April $2009(43.23 \mathrm{~cm})$ and then rose again until September 2009.

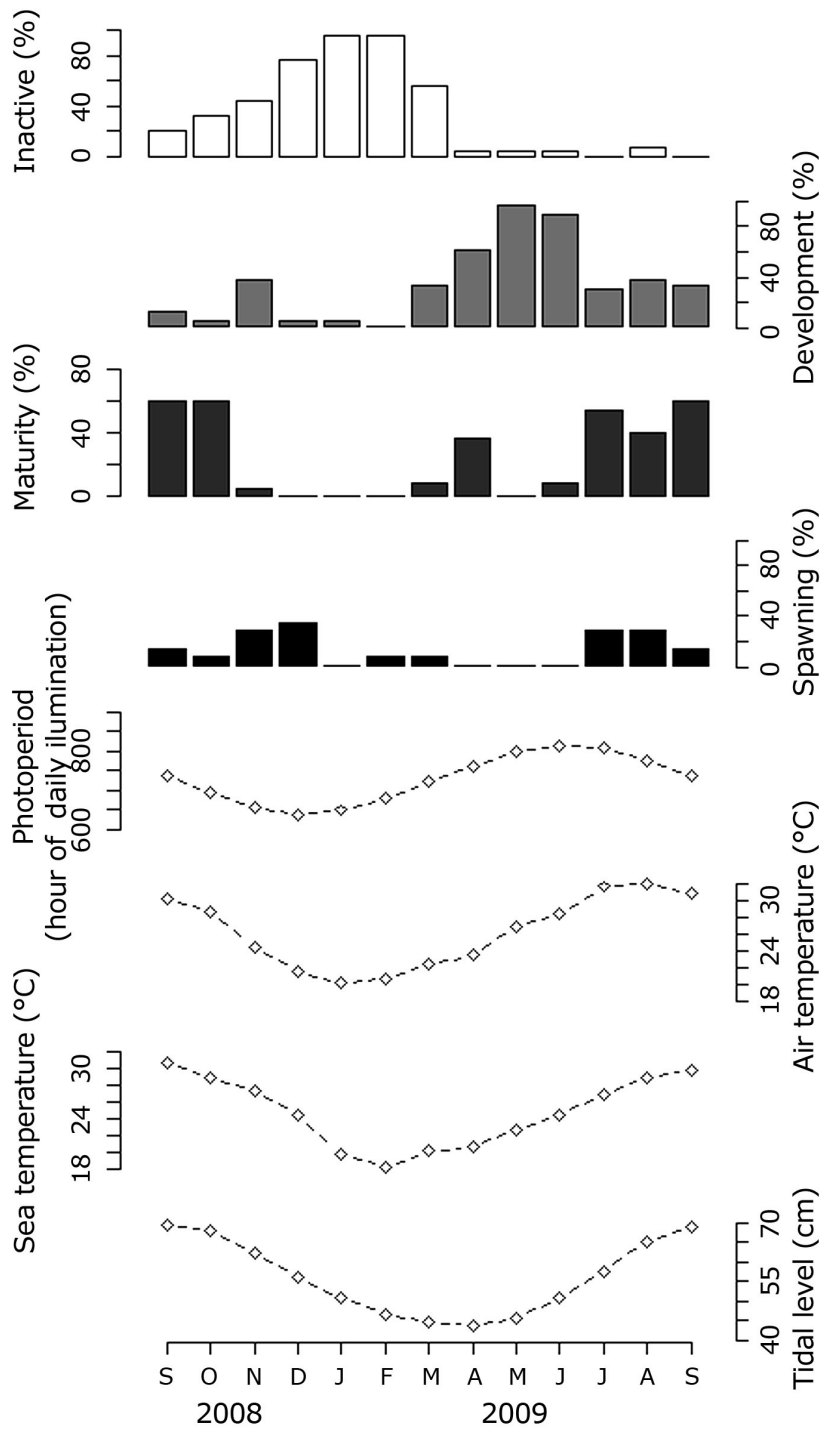

Figure 2. Frequency of occurrence of the reproductive stages of Chiton virgulatus and fluctuation in environmental parameters in Bahía de La Paz, Mexico / Frecuencia de las etapas del ciclo reproductivo de Chiton virgulatus y variaciones ambientales en Bahía de La Paz, México

<http://predmar.cicese.mx/programa/> 
A total of 325 C. virgulatus specimens were collected. Shell length oscillated between 24 to $46 \mathrm{~mm}$, with a mean total length of $32.18 \pm 4 \mathrm{~mm}$. Of these specimens, 112 were sexually undifferentiated, and the $\chi^{2}$ test showed that the sex ratio did not deviate significantly from 1:1.

The gonad of $C$. virgulatus is cylindrical, ranging in color from green to brown in females and from beige to pink in males, with the shade varying in relation to the degree of maturity.

Histologically, in both sexes the gonad is surrounded by connective tissue with invaginations (sex cords) projecting towards the gonad center; sex cords show a radial arrangement within the gonad. The connective tissue gives rise to germinal tissue from which germ cells originate; fully developed germ cells detach and gametes accumulate in the center of the gonad.

\section{UNDIFFERENTIATED STAGE}

No sex cells can be observed at this stage; only connective tissue is apparent (Fig. 3).

\section{DeVELOPING STAGE}

Males typically show numerous spermatogonia, spermatocytes, and spermatids growing along sex cords towards the lumen of the gonad, where some sperm cells can be found (Fig. 4A). In females, previtellogenic oocytes and some immature vitellogenic oocytes predominate, among which empty spaces can be observed (Fig. 4B).

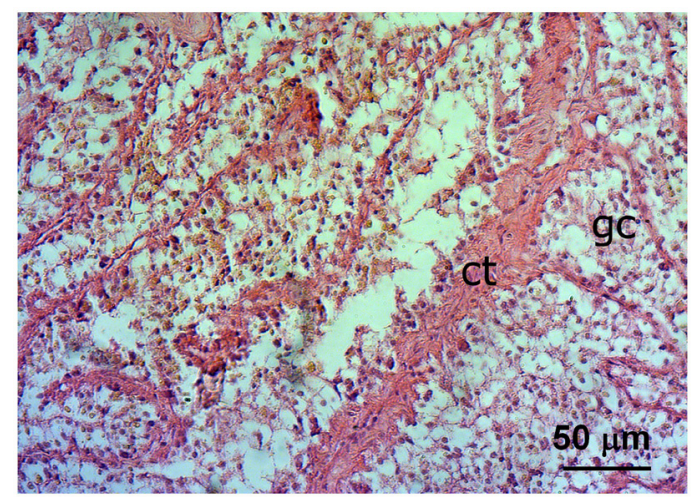

Figure 3. Histological section of undifferentiated gonads of Chiton virgulatus in Bahía de La Paz, Mexico. Connective tissue (ct), germ cells (gc). Hematoxylin-eosin staining. Bar $\mathbf{5 0} \boldsymbol{\mu m} /$ Corte histológico de gónada indiferenciada de Chiton virgulatus en Bahía de La Paz, México. Tejido conectivo (ct), células germinales (gc). Tinción hematoxilinaeosina. Barra $50 \mu \mathrm{m}$

\section{Mature Stage}

Male gonads characteristically show a reduced number of spermatocytes and spermatogonies along the sex cords but contain numerous sperm cells (Fig. 4C). In female gonads, mature vitellogenic oocytes predominate, the number of previtellogenic and immature vitellogenic oocytes has decreased, and the spaces between oocytes have disappeared as a result of oocyte growth (Fig. 4D).
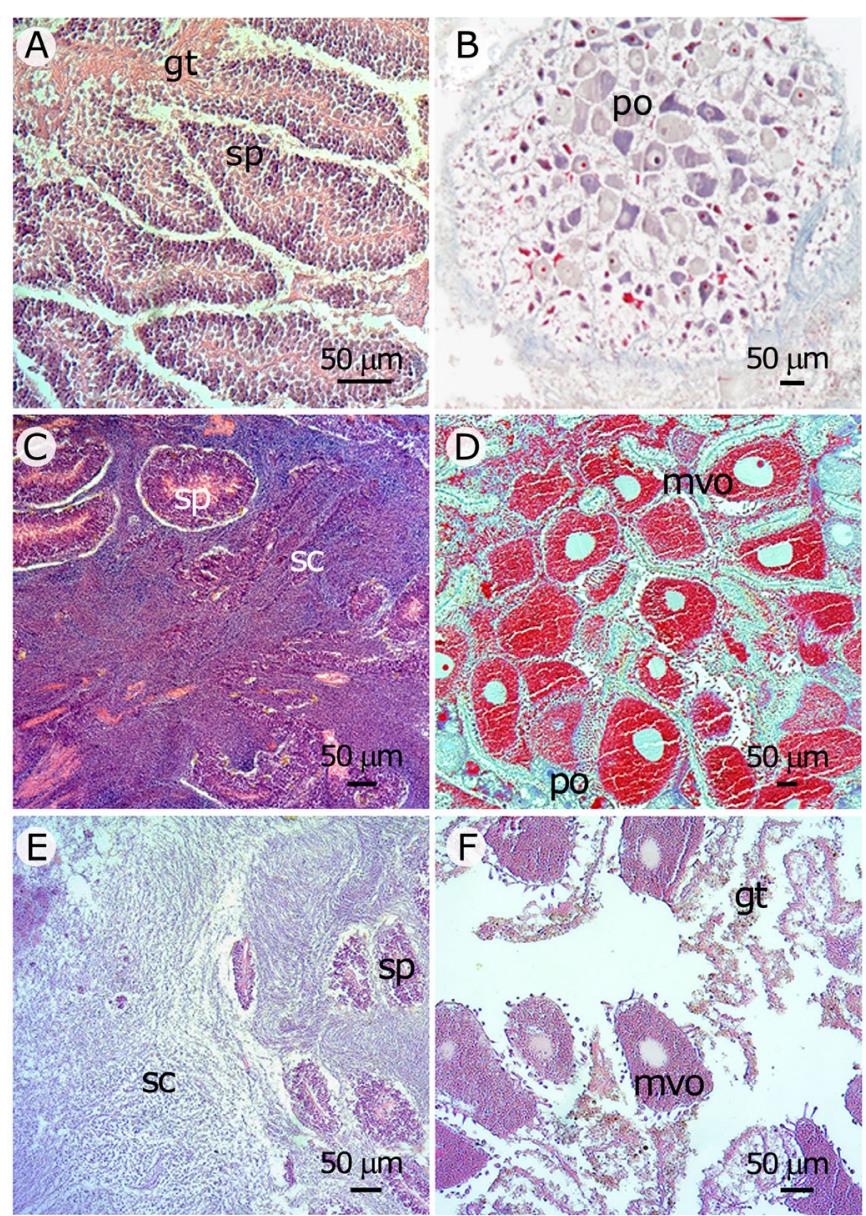

Figure 4. Histological section of gonads of Chiton virgulatus in Bahía de La Paz, Mexico. A) male gonad in the developing stage. Hematoxylin-eosin staining; B) female gonad in the developing stage. Masson's trichrome staining; C) mature male gonad. Hematoxylin-eosin staining; D) mature female gonad. Masson's trichrome staining; E) spawning male gonad. Hematoxylin-eosin staining; F) spawning female gonad. Hematoxylin-eosin staining. Spermatocytes (sp), sperm cells (sc), mature vitellogenic oocytes (mvo), previtellogenic oocytes (po), germinal tissue (gt) / Corte histológico de la gónada de Chiton virgulatus en Bahía de La Paz, México. A) gónada de macho en etapa de desarrollo. Tinción hematoxilina-eosina; B) gónada de hembra en etapa de desarrollo. Tinción tricrómica de Masson; C) gónada madura de macho. Tinción hematoxilinaeosina; D) gónada madura de hembra. Tinción tricrómica de Masson; E) gónada de macho en desove. Tinción hematoxilina-eosina; F) gónada de hembra en desove. Tinción hematoxilina-eosina. Espermatocitos (sp), espermatozoides (sc), ovocito vitelogénico maduro (mvo), ovocito previtelogénico (po), tejido germinal (gt) 


\section{SPAWNING STAGE}

In males, empty spaces in gonad tissue and some free sperm cells can be observed (Fig. 4E). In females, large voids are present between vitellogenic oocytes; connective tissue trabeculae appear disarranged (Fig. 4F).

\section{REPRODUCTIVE CYCLE}

The frequency of the reproductive stages is summarized in Figure 2. It shows that all stages occur throughout the year. The undifferentiated stage was more frequent in January and February (96\%), and dropped when AT was high $(\mathrm{R}=-0.75)$ and days were shorter $(\mathrm{R}=-0.83)$. The developing stage occurred more frequently from April to June $(\leq 60 \%)$. The maturity stage was observed mainly in the summer (July to October), correlated with high SST $(\mathrm{R}=0.79)$ and high AT $(\mathrm{R}=0.8)$, and when the tidal cycle shows higher values $(\mathrm{R}=0.64)$. The spawning stage also peaked in summer-fall, from September ( $8 \%$ ) to December (20\%); this stage coincides with high levels of the tidal cycle $(\mathrm{R}=0.57)$.

\section{OOCYTE DIAMETER}

The mean oocyte diameter showed significant differences between months $(P<0.05)$ (Table 1$)$. The mean oocyte diameter was larger in September $(100 \pm 52 \mu \mathrm{m})$ and October $(98 \pm 56 \mu \mathrm{m}) 2008$, then decreased gradually to December 2008, when the smallest mean diameter was recorded $(27 \pm 6 \mu \mathrm{m})$. Oocyte size remained low for a few months but then increased steadily until April 2009 $(81 \pm 41 \mu \mathrm{m})$. The largest mean diameter was recorded in August 2009 (114 $\pm 54 \mu \mathrm{m})$ (Fig. 5)

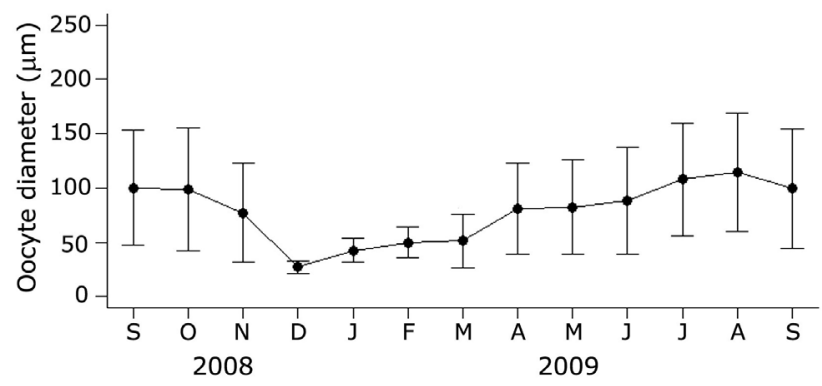

Figure 5. Monthly variations in mean oocyte diameter of Chiton virgulatus in Bahía de La Paz, Mexico. Bars represent the standard deviation / Variación mensual en el diámetro promedio mensual de los ovocitos de Chiton virgulatus en Bahía de La Paz, México. Las barras muestran la desviación estándar

Table 1. Significance of the post-hoc (Mann-Whitney) test after the paired comparison (Kruskal-Wallis test) of monthly mean oocyte diameter / Valores de significancia en la prueba post-hoc (Mann-Whitney) después de la comparación pareada (prueba de Kruskal-Wallis) del diámetro promedio mensual de los ovocitos

\begin{tabular}{|c|c|c|c|c|c|c|c|c|c|c|c|c|c|c|}
\hline & & Sep & Oct & Nov & Dec & Jan & Feb & Mar & Apr & May & Jun & Jul & Aug & Sep \\
\hline & & & & 018 & & & & & & & & & & \\
\hline & Sep & 1.000 & & & & & & & & & & & & \\
\hline$\infty$ & Oct & 1.000 & 1.000 & & & & & & & & & & & \\
\hline & Nov & 0.221 & 0.463 & 1.000 & & & & & & & & & & \\
\hline & Dec & $0.0001 *$ & $0.0001 *$ & $0.005^{*}$ & 1.000 & & & & & & & & & \\
\hline & Jan & $0.002 *$ & $0.004 *$ & 0.930 & 1.000 & 1.000 & & & & & & & & \\
\hline & Feb & 0.187 & 0.276 & 1.000 & 1.000 & 1.000 & 1.000 & & & & & & & \\
\hline & Mar & $0.0001 *$ & $0.0001 *$ & 0.463 & 1.000 & 1.000 & 1.000 & 1.000 & & & & & & \\
\hline & Apr & 1.000 & 1.000 & 1.000 & $0.001^{*}$ & 0.255 & 1.000 & $0.039^{*}$ & 1.000 & & & & & \\
\hline$\frac{a}{0}$ & May & 1.000 & 1.000 & 1.000 & $0.001 *$ & 0.202 & 1.000 & $0.026^{*}$ & 1.000 & 1.000 & & & & \\
\hline & Jun & 1.000 & 1.000 & 1.000 & $0.0001^{*}$ & 0.081 & 1.000 & $0.004^{*}$ & 1.000 & 1.000 & 1.000 & & & \\
\hline & Jul & 1.000 & 1.000 & 0.016 & $0.0001 *$ & $0.000^{*}$ & $0.047^{*}$ & $0.0001 *$ & 0.122 & 0.209 & 0.941 & 1.00 & & \\
\hline & Aug & 1.000 & 1.000 & 0.001 & $0.0001 *$ & $0.000 *$ & $0.013^{*}$ & $0.0001^{*}$ & $0.010^{*}$ & $0.019^{*}$ & 0.110 & 1.00 & 1.00 & \\
\hline & Sep & 1.000 & 1.000 & 0.439 & $0.0001^{*}$ & $0.004^{*}$ & 0.301 & $0.0001^{*}$ & 1.000 & 1.000 & 1.000 & 1.00 & 1.00 & 1.00 \\
\hline
\end{tabular}

* indicates significant differences 


\section{GONAD INDEX}

This index showed significant differences between months $(P<0.05)$. Peak values were recorded in September and October 2008 (30.52 and 30.75\%, respectively). The index decreased in November (14.4\%) and remained low until April (19.0\%), then increased gradually until September 2009 when it reached the peak value again $(36.2 \%$ ) (Table 2, Fig. 6).

\section{SIZE AT REPRODUCTIVE RECRUITMENT}

The length of $C$. virgulatus ranged from 24 to $46 \mathrm{~mm}$ (32.18 $\pm 4 \mathrm{~mm}$ ); the size at which at least $50 \%$ of the population is sexually mature was estimated at $31.42 \mathrm{~mm}$ in length. However, 24-mm specimens were observed that already showing signs of maturity (Fig. 7).

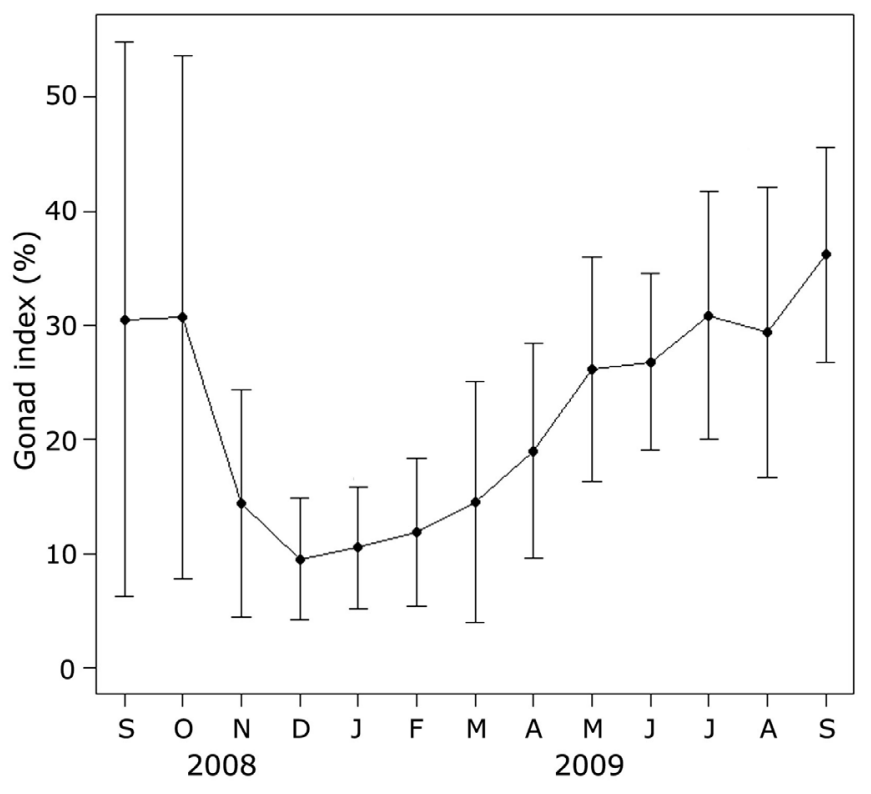

Figure 6. Monthly variations in gonad index values for Chiton virgulatus in Bahía de La Paz, Mexico. Bars represent the standard deviation / Variación mensual del valor del índice gonádico de Chiton virgulatus en Bahía de La Paz, México. Las barras muestran la desviación estándar

Table 2. Significance of the post-hoc (Mann-Whitney) test after the paired comparison (Kruskal-Wallis test) of gonad index per month / Valores de significancia en la prueba post-hoc (Mann-Whitney) después de la comparación pareada (prueba de Kruskal-Wallis) del índice gonádico por mes

\begin{tabular}{|c|c|c|c|c|c|c|c|c|c|c|c|c|c|c|}
\hline & & Sep & Oct & Nov & Dec & Jan & Feb & Mar & Apr & May & Jun & Jul & Aug & Sep \\
\hline & & \multicolumn{4}{|c|}{2018} & \multicolumn{9}{|c|}{2019} \\
\hline \multirow{4}{*}{$\frac{\infty}{\delta}$} & Sep & 1.000 & & & & & & & & & & & & \\
\hline & Oct & 1.000 & 1.000 & & & & & & & & & & & \\
\hline & Nov & 0.059 & 0.261 & 1.000 & & & & & & & & & & \\
\hline & Dec & $0.000^{*}$ & $0.002 *$ & 1.000 & 1.000 & & & & & & & & & \\
\hline \multirow{9}{*}{$\frac{a}{0}$} & Jan & $0.001 *$ & $0.009 *$ & 1.000 & 1.000 & 1.000 & & & & & & & & \\
\hline & Feb & $0.013^{*}$ & 0.069 & 1.000 & 1.000 & 1.000 & 1.000 & & & & & & & \\
\hline & Mar & 0.124 & 0.501 & 1.000 & 1.000 & 1.000 & 1.000 & 1.000 & & & & & & \\
\hline & Apr & 1.000 & 1.000 & 1.000 & 0.39 & 1.000 & 1.000 & 1.000 & 1.000 & & & & & \\
\hline & May & 1.000 & 1.000 & 0.078 & $0.001^{*}$ & $0.002 *$ & $0.018 *$ & 0.161 & 1.000 & 1.00 & & & & \\
\hline & Jun & 1.000 & 1.000 & $0.033^{*}$ & $0.001 *$ & $0.001 *$ & $0.007 *$ & 0.071 & 1.000 & 1.00 & 1.00 & & & \\
\hline & Jul & 1.000 & 1.000 & $0.001 *$ & $0.001 *$ & $0.0001 *$ & $0.0001^{*}$ & $0.003 *$ & 0.470 & 1.00 & 1.00 & 1.00 & & \\
\hline & Aug & 1.000 & 1.000 & $0.008 *$ & $0.001 *$ & $0.0001^{*}$ & $0.002 *$ & $0.019 *$ & 1.000 & 1.00 & 1.00 & 1.00 & 1.00 & \\
\hline & Sep & 1.000 & 0.822 & $0.0001 *$ & $0.001 *$ & $0.0001 *$ & $0.0001 *$ & $0.0001 *$ & $0.007 *$ & 1.00 & 1.00 & 1.00 & 1.00 & 1.00 \\
\hline
\end{tabular}

* indicates significant differences 


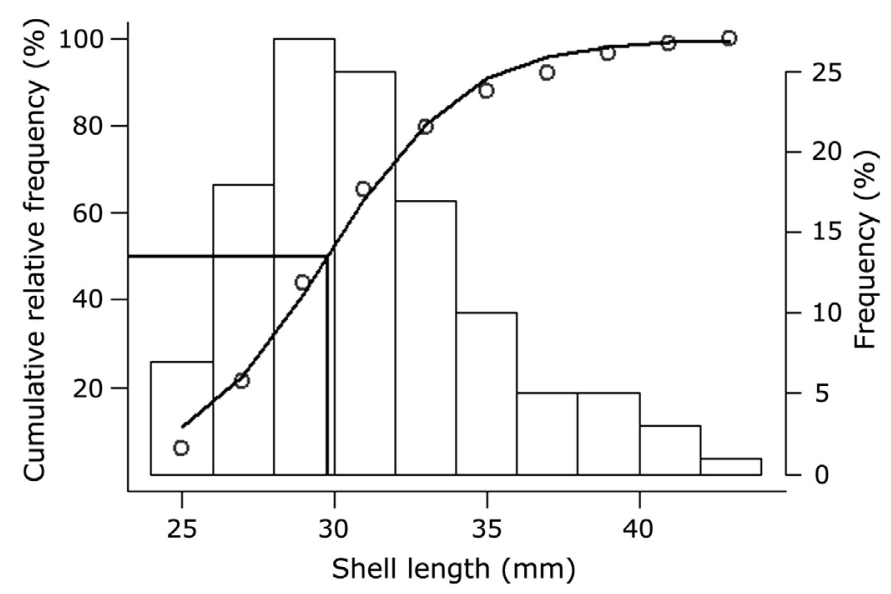

Figure 7. Size at reproductive recruitment in Chiton virgulatus in Bahía de La Paz, Mexico. September 2008-September 2009 / Longitud de reclutamiento a la reproducción de Chiton virgulatus en Bahía de La Paz, México. Septiembre 2008-Septiembre 2009

\section{DisCUSSION}

A feature of the Polyplacophora that allows differentiating males from females is gonad coloration. In males, mature gonads range from brown-red to orange through pinksalmon, while immature males feature white gonads. In females, female gonads display shades ranging from dark green to black (Glynn 1970, Pearse 1979, Rojas-Herrera 1988). In C. virgulatus, female gonads are brown-colored when immature and turn green as they mature; male gonads are white when immature and become pink at maturity. The anatomical structure of the gonad showed features similar to those already described for other chiton species, including Onithochiton quercinus, Chiton pelliserpentis, Plaxiphora paeteliana, C. articulatus, and Chiton albolineatus (Sakker 1984, Avila-Poveda \& AbadíaChanona 2013).

The sex ratio was 1:1 throughout the year. This differs from what has been reported for other polyplacophoran species, including Acanthopleura granulata and Chiton tuberculatus (Glynn 1970), Chiton cumingsii (Ishiyama 1995, Sotil 2004), and A. gemmata (Barbosa et al. 2009), in which the sex ratio is biased towards males. In this regard, Sotil (2004) pointed out that given the dispersal of sperm caused by sea turbulence, it is likely that the predominance of males in the population ensures oocyte fertilization by increasing the number of sperm cells in water. The 1:1 sex ratio observed in this $C$. virgulatus population suggests that it might have adopted other reproductive tactics for gamete dispersal, as suggested by the fact that it displays continuous spawning throughout the reproductive cycle.
C. virgulatus behaved like a partial spawner, a feature commonly observed in the class Polyplacophora, for example in Acanthopleura japonica (Yoshioka 1987a), Ischnochiton australis, and Chiton cumingsii.

Chiton virgulatus showed a reproductive peak in summer-fall (Fig. 3), similar to other chiton species, including Mopalia hindsii (Giese et al. 1959), Acanthopleura granulata, Chiton tuberculatus (Glynn 1970), Ischnochiton australis, and Liolophura gaimardi (Currier 1989). In winter-spring, a higher frequency of sexually undifferentiated organisms and a decrease in spawning frequency were observed. This might be related to the fact that the coastline where specimens were collected is influenced by bottom surges carrying a large amount of sediment (Cruz-Chávez 2008, Obeso-Nieblas et al. 2014). In Santa Monica Bay, USA, it was observed that Mopalia muscosa was not able to feed actively due to wave action and the presence of sand, which caused stress and led to gonad reabsorption (Boolootian 1965). The high frequency of undifferentiated organisms during the fall and spring could also be due to a conservative tactic, as observed for other molluscs such as Spondylus calcifer (Villalejo-Fuerte et al. 2002), Megapitaria squalida (Arellano-Martinez et al. 2006), and Panopea globosa (Aragón-Noriega et al. 2007). These species accumulate energy during part of the year; when favorable conditions occur (i.e., high temperature, trigger gonad development, and maturity). 
Reproductive cycles of marine invertebrates are commonly governed by interactions between exogenous factors such as photoperiod, tide level, and temperature, which act as environmental signals that trigger gonadal maturation in species such as Acanthopleura japonica (Yoshioka 1987a), Katherina tunicata (Himmelman 1978), Chiton cumingsii (Ishiyama 1995), Acanthopleura gemmata (Barbosa et al. 2009), and several other molluscs. In the present study, mature specimens of Chiton virgulatus were also determined to be more common on El Califin beach when SST and AT were high (29.9 and $30.6{ }^{\circ} \mathrm{C}$, respectively).

Similar to other chiton species such as $A$. japonica (Yoshioka 1987a), A. granulata, and C. tuberculatus (Glynn 1970), spawning of C. virgulatus occurs during the highest tides. Previous studies on Katharina tunicata and Mopalia hindisii in Santa Monica Bay, USA (Giese et al. 1959), and C. articulatus in Acapulco Bay, Guerrero, Mexico (Ramírez-Álvarez 2013) found that reproductive cycles are influenced by several local factors. Similarly, Himmelman (1978) found that the reproductive cycle of Katherina tunicata was not clearly related to temperature, photoperiod, lunar cycle, or tidal cycle. A probable explanation is that if $C$. virgulatus inhabits the intertidal zone, the populations may be affected by sea and air temperature as well as by the tidal cycle, being highly variable, not only over the annual cycle but also throughout the day.

The gonad development stage was directly affected by photoperiod. With shorter days, the frequency of sexually undifferentiated specimens increased and the frequency of developing organisms decreased. Although this relationship has not been reported for other chiton species, longer days have been found to trigger gonad development in invertebrates such as the starfish Pisaster ochraceus (Pearse \& Eernisse 1982), molluscs such as Octopus vulgaris (Numata \& Udaka 2009), and the bivalve Solen marginatus (López et al. 2005). In this regard, López et al. (2005) found a close relationship between the gametogenic process, reserve buildup, and food availability in water. The authors suggested that the high energy demand during reproduction is met by higher food intake, as a rise in photoperiod leads to an increase in organic matter availability. Therefore, these factors would be key for gonad maturation and spawning in this species.

This study shows that the gonad index is a good indicator of the different reproductive stages in C. virgulatus; this index has also been useful in C. articulatus (RamírezÁlvarez 2013). On the other hand, tracking the monthly mean oocyte diameter was not useful for this purpose, as those values showed no apparent correlation with the reproductive stages, likely due to the co-occurrence of oocytes and other development stages in the same gonad, as described by Vélez-Arellano et al. (2014).
Specimens collected at El Califin beach were small (mean total length $=32.18 \mathrm{~mm}$ ), compared to the reports of Abbott (1974) of 50-70 mm as maximum length. This might be due to hydrographic features, as El Califín beach is exposed to waves of moderate energy that cause a relatively intense abrasion of the rock surface, thus reducing the amount of biofilm and algae that can be used as food by chitons. Having more food available, chitons can obtain the energy required attain larger sizes and more frequent spawning events. However, Otaíza (1986), found larger chitons most exposed to waves. Chiton virgulatus is a polyplacophoran in which temperature and high tide influence the reproductive cycle, while increased daylight triggers gonad development

\section{ACKNOWLEDGMENTS}

The authors wish to thank the Secretaría de Investigaciones y Posgrado (SIP-IPN) and Beca de Estímulo Institucional de Formación de Investigadores (BEIFI) for the financial support granted to carry out this work. María Elena Sánchez-Salazar translated the manuscript into English.

\section{LITERATURE CITED}

Abadía-Chanona QY. 2015. Maduración gonádica, ciclo reproductivo y talla de madurez sexual del quiton Chiton (Chiton) articulatus (Mollusca: Polyplacophora) de la costa rocosa de Puerto Angel, Oaxaca, México. Tesis de Maestría en Ciencias, Centro Interdisciplinario de Ciencias Marinas, Instituto Politécnico Nacional, La Paz, 86 pp.

Abbott RT. 1974. American seashells, 663 pp. Van Nostrand, New York.

Aragón-Noriega EA, J Chavéz-Villalba, PE Gribben, E Alcántara-Razo, AN Maeda-Martinez, EM ArambulaPujol,AR García-Juárez \& R Maldonado-Amparo. 2007. Morphometric relationships, gametogenic development and spawning of the geoduck clam Panopea globosa (Bivalvia: Hiatellidae) in the central Gulf of California. Journal of Shellfish Research 26(2): 423-431.

Arellano-Martínez M, MF Quiñones-Arreola, BP CeballosVazquez \& M Villalejo-Fuerte. 2006. Reproductive pattern of the squalid callista Megapitaria squalida from Northwestern Mexico. Journal of Shellfish Research 25(3): 849-855.

Avila-Poveda OH. 2013. Annual change in morphometry and in somatic and reproductive indices of Chiton articulatus adults (Mollusca: Polyplacophora) from Oaxaca, Mexican Pacific. American Malacological Bulletin 31: 65-74.

Avila-Poveda OH \& QY Abadía-Chanona. 2013. Emergence, development, and maturity of the gonad of two species of chitons "Sea Cockroach" (Mollusca; Polyplacophora) through the early life stages. PLoS ONE 8(8): 1-12. < doi. org/10.1371/journal.pone.0069785>

Baqueiro CE, A Avilés-Quevedo, JA Masso-Rojas, M Muciño-Díaz, P Rogers-Nieto \& A Vélez-Barajas. 1992. Manual de métodos de muestreo y evaluación de poblaciones de moluscos y otros recursos bentónicos, 73 pp. Secretaría de Pesca, México D.F. 
Barbosa SS, M Byrne \& BP Kelaher. 2009. Reproductive periodicity of the tropical intertidal chiton Acanthopleura gemmata at One Tree Island, Great Barrier Reef, near its southern latitudinal limit. Journal of the Marine Biological Association of the United Kingdom 89(2): 405-411.

Barón P \& NF Ciocco. 2001. Reproductive cycle of the clam Tellina petitiana d'Orbygny, 1846, in Nuevo Gulf (Argentina). The Veliger 44(4): 370-380.

Boolootian RA. 1965. On growth feeding and reproduction in the chiton Mopalia muscosa of Santa Monica Bay. Helgoland Marine Research 11(3-4): 186-199.

Cruz-Chávez FD. 2008. Estudio geológico marino del abanico delta El Califín, Baja California Sur, México. Tesis de Licenciatura, Universidad Autónoma de Baja California Sur, La Paz, 76 pp.

Currier RD. 1989. Reproductive periodicity of three species of chitons at a site in New South Wales, Australia (Mollusca: Polyplacophora). Invertebrate Reproduction and Development 17(1): 25-32.

Eernisse DJ. 1988. Reproductive patterns in six species of Lepidochitona (Mollusca: Polyplacophora) from the Pacific Coast of North America. The Biological Bulletin 174: 287-302.

Flores-Campaña LM, MA González-Montoya, MA OrtizArellano \& JF Arzola-González. 2007. Estructura poblacional de Chiton articulatus en las islas Pájaros y Venados de la bahía de Mazatlán, Sinaloa, México. Revista Mexicana de Biodiversidad 78: 23-31.

García-Ibáñez S, R Flores-Garza, P Flores-Rodríguez, J Violante-González, A Valdés-González \& FG Olea-de la Cruz. 2013. Diagnóstico pesquero de Chiton articulatus (Mollusca: Polyplacophora) en Acapulco, México. Revista de Biología Marina y Oceanografía 48(2): 293-302.

Giese AC, JS Tucker \& RA Boolootian. 1959. Annual reproductive cycles of the chitons, Katharina tunicata and Mopalia hindsii. The Biological Bulletin 117: 81-88.

Glynn PW. 1970. On the ecology of the Caribbean chitons Acanthopleura granulata Gmelin and Chiton tuberculatus Linné: Density, mortality, feeding, reproduction, and growth. Smithsonian Contributions to Zoology 66: 1-28.

Grant A \& PA Tyler. 1983. The analysis of data in studies of invertebrate reproduction. II. The analysis of oocytes size frequency data, and comparison of different types of data. International Journal of Invertebrate Reproduction 6: 259-269.

Himmelman JH. 1978. The reproductive cycle of Katherina tunicata Wood and its controlling factors. Journal of Experimental Marine Biology and Ecology 31: 27-41.

Holguin-Quiñones OE \& EJ Michel-Morfín. 2002. Distribution, density and length-weight relationship of Chiton articulatus Sowerby, 1832 (Mollusca Polyplacophora) on Isla Socorro, Revillagigedo Archipelago, México. Journal of Shellfish Research 21(1): 239-241.

Ishiyama VC. 1995. Reproducción del Chiton cumingsii (Polyplacophora, Chitonidae) de la Bahía de Ancón, Lima. Boletín de Lima 100: 203-210.

Jaramillo R \& J Navarro. 1995. Reproductive cycle of the Chilean ribbed mussel Aulacomya ater (Molina, 1782). Journal of Shellfish Research 14(1): 165-171.
López J, C Rodríguez \& JF Carrasco. 2005. Comparación del ciclo reproductor de Solen marginatus (Pulteney, 1799) (Mollusca: Bivalvia) en las rías del Eo y Villaviciosa (Asturias, noroeste de España): relación con las variables ambientales. Boletín del Instituto Español de Oceanografía 21(1/4): 317-327.

Luna GL. 1968. Manual of histological staining methods of the Armed Forces Institute of Pathology, 258 pp. McGrawHill, New York.

Mackie GL. 1984. Bivalves. In: Tompa AS, NH Verdonk \& J Van Der Biggelaar (eds). The Mollusca: Reproduction 7: 351-418. Academic Press, New York.

Morfin-Jiménez AA, S García-Ibáñez, R Flores-Garza \& FG Olea-De-La-Cruz. 2014. Observaciones sobre el ciclo reproductivo de Chiton articulatus (Mollusca: Polyplacophora) en Playa las Brisas, Acapulco, Guerrero, México. Foro de Estudios Sobre Guerrero 1(1): 444-448.

Numata H \& H Udaka. 2009. Photoperiodism in Mollusks. In: Nelson RJ, DL Denlinger \& DE Somers (eds). Photoperiodism: The biological calendar, pp. 173-189. Oxford University Press, Oxford

Obeso-Nieblas M, JH Gaviño-Rodríguez, H Obeso-Huerta \& SI Muñoz-Casillas. 2014. Spatial thermohaline variability, water masses and geostrophic circulation in Bahía de La Paz, Gulf of California. Revista de Biología Marina y Oceanografía 49(3): 413-426.

Otaíza RD. 1986. Patrones de distribución vertical de chitones y efecto de pastoreo de Chiton granosus en roqueríos intermareales de Chile central. In: Santelices B (ed). Simposio Internacional. Usos y funciones ecológicas de las algas marinas bentónicas. Monografías Biológicas 4: 173190. Ediciones Universidad Católica de Chile, Santiago.

Pearse J. 1979. Polyplacophora. In: Giese AC \& JS Pearse (eds). Reproduction of marine invertebrates. Lesser classes, molluscs: Pelecypods 5: 27-93. Academic Press, New York.

Pearse JS \& J Eernisse. 1982. Photoperiodic regulation of gametogenesis and gonadal growth in the sea star Pisaster ochraceus. Marine Biology 67: 121-125.

Ramírez-Álvarez C. 2013. Ciclo reproductivo de Chiton articulatus Sowerby en Broderip y Sowerby, 1832 (Mollusca; Polyplacophora) en Acapulco, Guerrero, México. Tesis de Licenciatura, Universidad Autónoma de Guerrero, Acapulco, 72 pp.

Ramírez-Álvarez C, N Vélez-Arellano, FA GarcíaDomínguez, S García-Ibañez \& C Ituarte. 2014. Hermaphroditism in two populations of Chiton articulatus (Mollusca: Polyplacophora) from the Eastern tropical coast of Mexico. Invertebrate Reproduction and Development 58: 49-52.

Ríos-Jara E, M Pérez-Peña, E López-Uriarte, I EncisoPadilla\& E Juárez-Carrillo. 2006. Biodiversidad de moluscos marinos de la costa de Jalisco y Colima, con anotaciones sobre su aprovechamiento en la región. En: Jiménez-Quiroz MC \& E Espino-Barr (eds). Los recursos pesqueros y acuícolas de Jalisco, Colima y Michoacán. Marco ambiental, biología de moluscos, pp. 103-120. SAGARPA, México.

Rojas-Herrera A. 1988. Análisis biológico-Pesquero de la cucaracha de mar (Chiton articulatus Sowerby, 1832) de Acapulco, Guerrero, México. En: Memorias IX Congreso Nacional de Zoología 1: 151-156. Universidad Juárez Autónoma de Tabasco, Villahermosa.

Vol. $55, N^{\circ} 1,2020$

Revista de Biología Marina y Oceanografía 
Rose R, R Dybdalh \& S Harders. 1990. Reproductive cycle of the Western Australian Silverlip Pearl oyster Pinctada maxima (Jameson) (Mollusca: Pteriidae). Journal of Shellfish Research 9(2): 261-272.

Sakker ER. 1984. Sperm morphology, spermatogenesis and spermiogenesis of three species of chitons (Mollusca, Polyplacophora). Zoomorphology 104: 111-121.

Sakker ER. 1986. Seasonal reproduction cycles of three Australian species of chitons (Mollusca: Polyplacophora). Invertebrate Reproduction and Development 10: 1-16.

Sastry A. 1979. Pelecypoda (Excluding Ostreidae). In: Giese AC \& JS Pearse (eds). Reproduction of Marine Invertebrates 5: 113-292. Academic Press, New York.

Siqueiros-Beltrones DA \& U Argumedo-Hernández. 2012. Diatom diversity in the in situ diet of Chiton virgulatus (Mollusca: Polyplacophora) from Baja California Sur, Mexico. Hidrobiológica 22(3): 267-281.

Soliman F, MA Hussein, AH Elmaragchi \& TN Yousif. 1996. Reproductive ecology of the common rock chiton Acanthopleura gemmata (Mollusca; Polyplacophora) in the Nortwestern Coast of the Red Sea. Qatar University Science Journal 16(1): 95-102.

Somerton DA. 1980. Fitting straight lines to Hiatt growth diagrams: a-revaluation. ICES Journal of Marine Science 39: $15-19$.

Sotil CGE. 2004. Variación estacional de la madurez gonadal y oogénesis de Chiton cumingsii Frembly, 1827 de Bahía Ancón, Lima-Perú. Tesis de Licenciatura, Universidad Nacional Mayor de San Marcos, Lima, 63 pp.
Spearman C. 1904. The proof and measurement of association between two things. The American Journal of Psychology 15(1): 72-101.

Vélez-Arellano N, M Shibayama, E Ortíz-Ordoñez, A SilvaOlivares; M Arellano-Martínez \& F García-Domínguez. 2014. Histological description of oogenesis in Chiton virgulatus (Mollusca: Polyplacophora). International Journal of Morphology 32(2): 608-613.

Villalejo-Fuerte M \& BP Ceballos-Vázquez. 1996. Variación de los índices de condición general, gonádico y de rendimiento muscular en Argopecten circularis (Bivalvia: Pectinidae). Revista de Biología Tropical 44: 591-594.

Villalejo-Fuerte M, M Arellano-Martínez, BP CeballosVázquez \& F García-Domínguez. 2002. Reproductive cycle of Spondylus calcifer Carpenter, 1857 (Bivalvia: Spondylidae) in the "Bahía de Loreto" National Park, Gulf of California, Mexico. Journal of Shellfish Research 21: 103-108.

Yoshioka E. 1987a. Annual reproductive cycle of chiton Acanthopleura japonica. Marine Biology 96(3): 371-374.

Yoshioka E. 1987b. Environmental cue to initiate gametogenesis in the chiton Acanthopleura japonica. Venus: The Japanese Journal of Malacology 46: 173-177.

Zar JH. 2010. Biostatistical analysis, 944 pp. Prentice Hall, Upper Saddle River.

Received 9 May 2018 and accepted 10 December 2019

Editor: Claudia Bustos D. 